を図り，被験者として参加する一般市民の信頼と 協力を得た上で，この三者からなるよきリレーシ ヨンシップを醸成することが，何よりもこれから の治験を実施する際に重要なことであろう.
文献

1）平成 9 年度厚生科学研究：新 GCP 普及定着総合研究最 終報告書, 1998

2）新 GCP の普及定着に向けて，株式会社ミクス，東京， 1998

\title{
用語解説
}

\section{Kartagener 症候群}

Kartagener 症侯群は，1933年，M Kartagenerによって最初の報告がなされた，(1) 内臓逆位，(2)慢性副鼻腔炎，(3)気管支拡張症 を特徵とする疾患群である．常染色体劣性遺 伝であり，発現率は先天性心奇形の中で $1 \%$ 以下といわれ，内臟逆位のほか，種々の奇形 や腫瘍の合併も多く認められる，さらに全身 の線毛系組織の超微形態と機能の異常が特徵 であり, primary ciliary dyskinesia あるいは immotile cilia syndromeの一型とされる. 気道の線毛運動低下は咳, 痰や反復する気道 感染を起こし，これが気管支拡張症の原因の 1つと考えられている.

学校心臟検診の場などでまれに右胸心を発 見するが，本症候群も忘れてはならない鑑別 疾患の 1 つである.

$$
\text { (聖マリアンナ医科大学第 } 2 \text { 内科至宅良彦) }
$$

